\title{
THE PROBLEM OF INSTITUTIONAL TRUST IN UKRAINE AND EUROPE: A COMPARATIVE ANALYSIS
}

\author{
Mykola Izha' ${ }^{1}$ Olena Knyazeva ${ }^{2}$, Tetyana Pakhomova ${ }^{3}$
}

\begin{abstract}
The article presents the results of studying the formation of institutional trust, which will help to clarify and, at the same time, raise questions regarding the determination of the level of trust in state and political institutions in Ukraine and in modern European countries. In the context of the study, the tasks were considered to identify the factors that influence the formation of citizens' trust in political institutions, namely: the effectiveness of the activities of political institutions; personal experience of interaction of citizens with representatives of authorities; the level of trust in the state as a whole, which can be transferred to individual state institutions. Analyzing the data from the Rounds (waves) 1-9 of the European Social Survey (ESS) in 2002-2018, the level of confidence in Ukraine's political and public institutions and in the other European countries is compared. The analysis makes it possible to determine the factors that are present at the supra-individual level (at the country level) and which can influence the public policy of the state. The results of the study can be used to suggest possible measures to increase public confidence in major public institutions.
\end{abstract}

Key words: trust, institutional public trust, public authorities, political institutions, level of trust.

JEL Classification: H83, P26

\section{Introduction}

Despite the efforts of scientists around the world, it is still unknown how long a pandemic associated with the spread of the COVID-19 virus will last, how to overcome it and reduce the risks of other crises in the economy, politics, social and other spheres. In order to overcome the crisis, governments in many countries have to take unpopular measures of public administration. The effectiveness of these measures depends largely on the level of trust between the institutions of government and society.

The results and depth of the many studies that have already been carried out, the high relevance and variety of the findings, indicate that the problem of public trust in political and public institutions has not lost its relevance, especially recently. It is well known that trust is one of the basic factors that determines not only interpersonal, but also social, economic political relations at different levels of existence and development of society.
Following the well-known Polish sociologist Piotr Sztompka, we will consider trust in political and public institutions as one of the varieties of public (institutional) trust (Sztompka, 2012). In the work, Trust is the Basis of Society (2012), in Chapter 3, "Varieties of Trust", P. Sztompka identifies two main types of trust: interpersonal and social. According to P. Sztompka, when we consider trust in institutions and organizations, "we are entering the territory of a special kind of trust, which is defined as public". School, university, army, church, court, police, bank, exchange, government, parliament, enterprise are the typical objects of this category. The degree of trust that people give to different institutions varies depending on the society and also changes over time" (Sztompka, 2012 , p. 119). In our view another important form of institutional trust is "procedural trust," which P. Sztompka defines as "trust in institutional practices or procedures based on the belief that compliance will have the greatest effect" (Sztompka, p. 119). The

\footnotetext{
Corresponding author:

${ }^{1}$ Odesa Regional Institute for Public Administration,

National Academy for Public Administration under the President of Ukraine, Ukraine.

E-mail: director@oridu.odessa.ua

ORCID: https://orcid.org/0000-0002-7263-6193

${ }^{2}$ Odesa Regional Institute for Public Administration,

National Academy for Public Administration under the President of Ukraine, Ukraine.

E-mail: knyazeva.elena.mail@gmail.com

ORCID: https://orcid.org/0000-0001-5625-768X

${ }^{3}$ Odesa Regional Institute for Public Administration,

National Academy for Public Administration under the President of Ukraine, Ukraine.

E-mail: tipakhomova@ukr.net

ORCID: https://orcid.org/0000-0001-9940-1418
} 
author cites examples from the fields of politics and economics: "trust in democratic procedures (elections, conditions of representation, majority voting), which are recognized as the best ways to satisfy the interests of the largest part of the population and achieve the most reasonable compromises in a conflict of interest situation. In Section 8, “Trust in Democracy," the author defines trust in the state and its institutions as "public trust or vertical trust, as opposed to the horizontal one existing between citizens" (Sztompka, p. 366). The term "vertical" implies that trust exists between partners at different levels within a defined hierarchy, namely, at the levels of power (Sztompka, p. 366). It should be noted that in the aspect of research of civil society and the state, modern researchers as the most important distinguish between the problem of trust in public authorities (Trust in Political Institutions) and the problem of the relationship of institutional trust (Political of Institutional Trust) with interpersonal Trust (Lukin, 2005; Terin, 2018).

Within the framework of the study of political trust, two theoretical traditions of interpretation of political trust have emerged: cultural and institutional.

The cultural theoretical tradition of the interpretation of trust is represented by the theories of political culture (Baker, 1981; Inglehart, Welzel, 2005). These theories are based on the hypothesis of exogenous nature of political trust in relation to the political sphere. From a cultural point of view, political trust is the continuation of interpersonal trust, which is formed during the early socialization period and influences further individual evaluations of political institutions. Political trust is seen here as a component of social capital, and interpersonal trust (based on the exogeneity of the origin of political trust) is seen as the basis for building political trust (Keenan, 1986; Jowitt, 1992; Hedland, 1999; Joyce, 1984; Fukuyama, 1995).

Institutional conceptual interpretations of political trust focus on the endogenous nature of trust and the rationality of trust (i.e. its conditionality by internal political factors related to the political and economic course of government, citizens' assessment of the level of policy effectiveness in the country). The logic behind this approach is that institutional trust is the consequence, not the cause, of effective political institutions. If political institutions operate effectively, they generate trust, otherwise skepticism and mistrust. Institutional approaches to the definition of trust are presented in the works of such scientists as Rose (1995), Newton (1999), Mutz (1998), Dazgupta (2019), S. Skowronek (1982), K. Shepsl (2017), and others.

To summarize, we can conclude that the following aspects of institutional trust exist, namely:
- identification with the values or goals of the institutions (our president, our army, our science etc.); identification with political leaders who lead or represent institutions;

- possibility of access to the services (resources) of the respective institute, potential access to it;

- pragmatic assessment of the functions performed by the institutes;

- illusions, hopes for benefits, protection against threats caused by expectations of institutional dysfunctions;

- understanding of the cost of compliance and non-compliance with institutional conditions and requirements, the willingness to minimize the repressive pressure of the respective institute by recourse to resources of other groups, etc.

The aim of the study. The purpose of our study is to determine the role of institutional trust in the functioning of public institutions in Ukraine and the European countries, to analyze the differences of citizens' trust in state institutions of different countries, to determine how much the level of citizens' trust in different countries depends on their individual characteristics. We have tried to identify the key factors influencing citizens' confidence in political institutions by comparing trends in the level of trust in political institutions in Ukraine and Europe in the context of the laws that operate in high or low confidence countries.

Materials and methods. Over the last 20 years, a large-scale archive of national and international sociological research data has been accumulated, which allows to solve many research problems.

\section{Statement of the basic material}

The European Social Survey $(E S S)^{1}$ is a unique sociological monitoring project. Its organizers received the most prestigious Descartes Science Prize in Europe in 2005, the first in its history to receive for the research in the field of the social sciences. Dozens of the European countries represented in the project leadership participate in this project, in the committees responsible for the preparation and implementation of the monitoring, in the national coordination structures by the best specialists in various aspects of comparative monitoring sociological research. The uniqueness of the project is determined, first and foremost, by rigorous methodological and organizational requirements, the compliance of which gives reason to believe with certainty that the data obtained in 29 European countries in 2002-2018 open up a real possibility to compare numerous indicators of trust in political and public institutions.

ESS surveys are conducted according to strict international standards. ESS-2002-2019 includes a basic thematic module on various aspects of citizen

\footnotetext{
${ }^{1}$ European social survey // Data and documentation [online]. Accessed: 4.01.2020.
} 

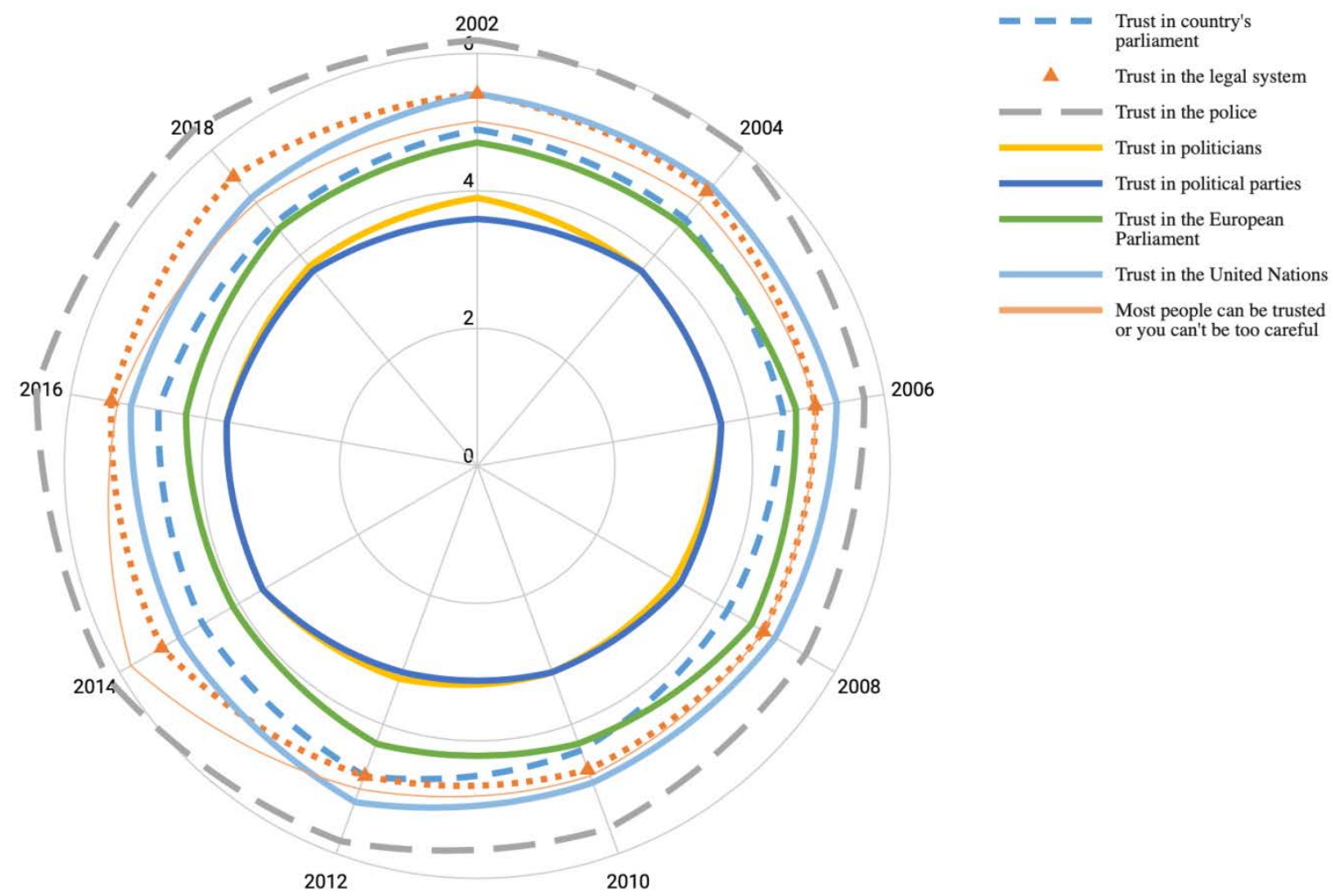

Figure 1. Political and public confidence radii according to ESS Round 1-9

Source: authors

interaction with political and public institutions. In it, institutional trust and attitudes toward power are measured through the following questions:

(1) "Please tell us how much you personally trust in the Parliament... Politicians, police, political parties, the European Parliament, the UN?”. A scale from 0 to 10 is used for the answer, where " 0 " means that you absolutely do not trust institutions, and " 10 " - for the institutions you fully trust;

(2) "How satisfied are you with the work of the government of the country?". To answer the second question, a 10 point scale is offered (from 0 - completely dissatisfied, 10 - completely satisfied) .

We decided to verify this statement, based on the results of the European Social Survey. A confidence index (ID) was also used to compare and identify prevailing trends in the European countries in the analysis, which was calculated as an average of the scale from 0 to 10 .

The empirical analysis begins with a simple description of the averages. Although the information given in Figures 1-6 is the confidence-based data and not all countries have participated in all rounds of the European Social Survey, they draw a consistent picture.

Figure 1 shows a pie chart - Radii of institutional and generalized trust, built on the basis of average confidence indicators in each round of the European
Social Research from 2002 to 2018. The diagram clearly shows that the highest level of trust among the countries participating in the project is enjoyed by the police. The average indicator of the level of trust in police for the entire study period is 6 points on an 11-point scale, the maximum level was recorded in 2002 - 6.2 points, the minimum in 2008 - 5.5 (see Table 2). The lowest level of trust is enjoyed by political parties and politicians (the average indicator of trust in political parties for the entire study period is $3.5 \mathrm{bp}$, for politicians $-3.6 \mathrm{bp}$ ). Confidence in these institutions has noticeably decreased during the 2008-2009 crisis. Next, we will dwell on each institute in more detail.

Parliament. The highest level of confidence of the legislative (representative) branch of state power is most often expressed by citizens of the countries of Northern and Central Europe (see Annex 1). The average index of confidence in its national parliaments in Norway, Switzerland, Finland, Denmark and Sweden for the years 2002-2019 is the highest between 5.9 and 6.4 points. Ukraine, Poland, Croatia and Bulgaria belong to the group of countries with a negative index of confidence in the national parliament. The lowest level of population support in Europe is used by the Ukrainian Parliament (data of 2008-2012).

As for the dynamics of the level of confidence, according to the study, there are three clusters of countries (Figure 1): 
Vol. 1, No. 4, 2020

Three Seas Economic Journal

Table 1

Trust level. Average indicators among all countries (ESS Round 1-9, mean)

\begin{tabular}{|l|c|c|c|c|c|c|c|c|c|}
\hline & $\begin{array}{c}\text { Round 1 } \\
(2002)\end{array}$ & $\begin{array}{c}\text { Round 2 } \\
(2004)\end{array}$ & $\begin{array}{c}\text { Round 3 } \\
(2006)\end{array}$ & $\begin{array}{c}\text { Round 4 } \\
(2008)\end{array}$ & $\begin{array}{c}\text { Round 5 } \\
(2010)\end{array}$ & $\begin{array}{c}\text { Round 6 } \\
(2012)\end{array}$ & $\begin{array}{c}\text { Round 7 } \\
(2014)\end{array}$ & $\begin{array}{c}\text { Round 8 } \\
(2016)\end{array}$ & $\begin{array}{c}\text { Round 9 } \\
(2018)\end{array}$ \\
\hline Trust in country's parliament & 4.9 & 4.7 & 4.5 & 4.2 & 4.4 & 4.8 & 4.6 & 4.7 & 4.6 \\
\hline Trust in the legal system & 5.4 & 5.2 & 5 & 4.8 & 4.7 & 4.8 & 5.3 & 5.4 & 5.5 \\
\hline Trust in the police & 6.2 & 6 & 5.7 & 5.5 & 5.6 & 5.8 & 6.2 & 6.5 & 6.4 \\
\hline Trust in politicians & 3.9 & 3.7 & 3.6 & 3.3 & 3.2 & 3.3 & 3.6 & 3.7 & 3.8 \\
\hline Trust in political parties & 3.6 & 3.7 & 3.6 & 3.4 & 3.2 & 3.2 & 3.6 & 3.7 & 3.7 \\
\hline Trust in the European Parliament & 4.7 & 4.6 & 4.7 & 4.6 & 4.3 & 4.3 & 4.1 & 4.3 & 4.5 \\
\hline Trust in the United Nations & 5.4 & 5.3 & 5.3 & 5 & 4.9 & 5.2 & 5 & 5.1 & 5.1 \\
\hline $\begin{array}{l}\text { Most people can be trusted or you } \\
\text { cannot be too careful }\end{array}$ & 5 & 5 & 5 & 4.8 & 4.8 & 5 & 5.8 & 5.3 & 5 \\
\hline
\end{tabular}

Source: authors

The first is that the level of trust has a positive dynamic, namely Lithuania, Norway, the Netherlands, Estonia, Germany;

The second is that the level of trust remains almost unchanged: Belgium, Sweden, the UK;

The third is that the level of trust has a negative dynamic: Ukraine, Greece, Spain, Cyprus, Croatia.

Analyzing the nature of citizens' trust in national parliaments, many researchers point out that a lack of trust is more common in countries with "new" democracies (Inglehart, 2005). One of the reasons for the backlog is the insufficiently long term effective functioning of democratic political institutions.

How stable is this order? Has the result been some kind of random aberration? We tested our results using data from other ESS waves from 2002 to
2019 (Table 1): sets of leaders and outsiders, despite the fact that the list of participating countries differed by year, intersected and yielded similar results for those countries that hit the intersecting part of the sample. To group countries by level of confidence in national parliaments we used another indicator: the integral trust indicator for national parliaments, which was calculated as the average of all confidence indicators across the country for all the rounds in which we participated. As a result, we got the following picture: Denmark (6.4), Norway (6.2 on a 10-point scale) lead the Parliament, followed by Switzerland (6.0) and Finland (5.9) [See Annex 1]. The group closes with Bulgaria (2.3), Ukraine (2.6), Poland, Lithuania (3.2).

Thus, we can formulate two preliminary conclusions. Firstly, countries differ greatly in average confidence in

$2 \longrightarrow 1,7$

1,1

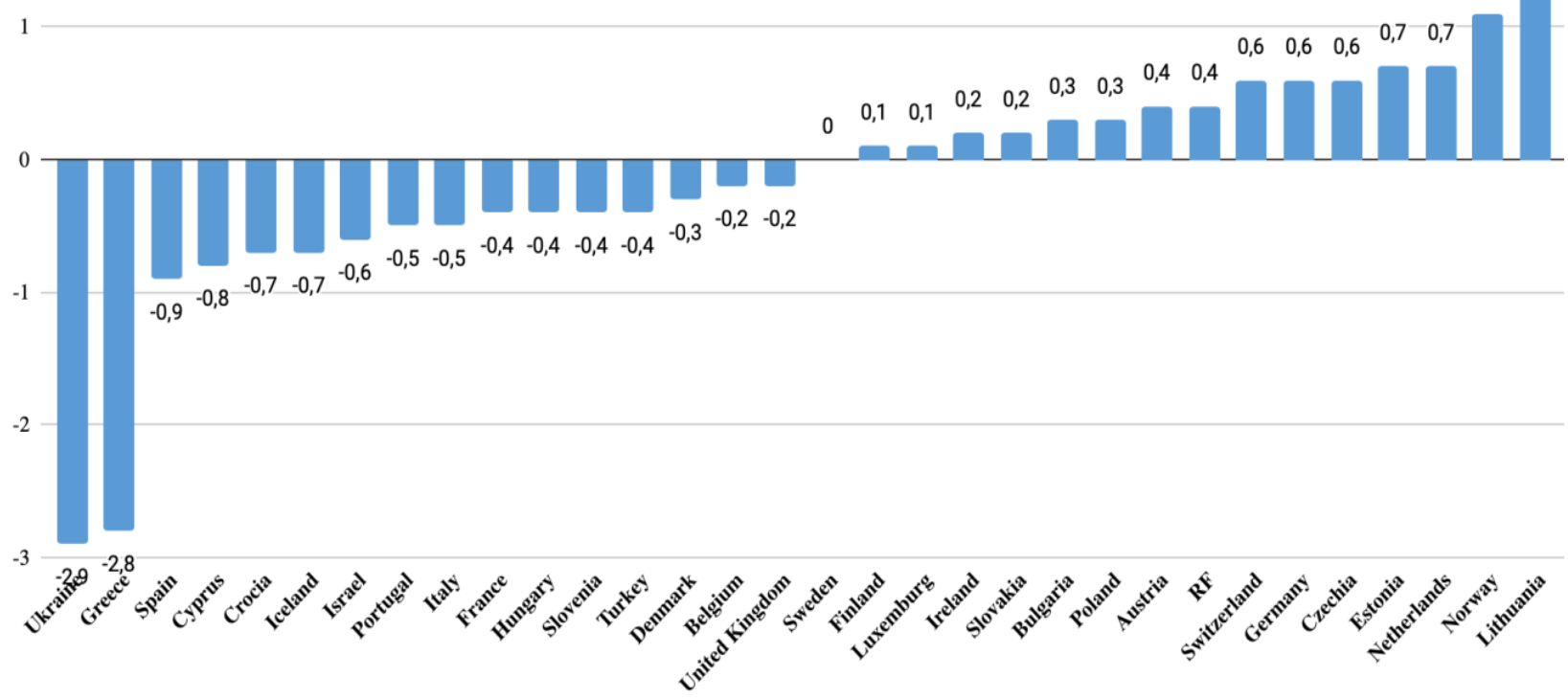

Figure 2. Dynamics of trust in national parliaments among ESS Round 1-9 project participants (difference in scores (11-point averages) between the first and last survey)

Source: authors 
national parliaments. Secondly, this distribution seems to be quite stable and almost independent of the year of the survey.

Trust in police. In most European countries, people trust in police more than other political and public institutions (see Annex 2). The Police Confidence Index demonstrates that the balance of trust and confidence in almost all European countries is positive. And in countries such as Finland (8), Denmark (7.8), Iceland (7.6) have the highest rate, ie the police in these countries fully deserve the mass trust of citizens. The low police confidence index is observed only in three post-Soviet countries - Ukraine (2.5), Bulgaria (3.7) and the Russian Federation (3.8). According to the confidence index of law enforcement agencies, Ukraine is at the top of the European rating.

It should be noted that, compared to the confidence of national parliaments, most countries participating in the ESS project have a positive trend. Only in two

Only in two of the surveyed countries - Ukraine and Israel - did the confidence level drop by 1 point, while in the other four countries with negative dynamics the decline was insignificant (see Figure 3 ).

Political parties. The confidence rating of politicians is also consistent with the confidence rating of political parties as a whole (see Figure 4). As in the analysis of trust in political parties, most countries are characterized by a situation where the majority of citizens express varying degrees of distrust in their countries.

Outsiders in the level of trust in political parties also stand out in Eastern and Southern Europe: Latvia (1.6), Bulgaria (1.9), Croatia (2.1); the leaders are mainly the states of Northern and Central Europe Denmark (5.4), the Netherlands (5.1), Norway (5.0) (see Annex 3).
Figure 5 shows a higher level of trust of Europeans in the UN and the European Parliament than in national parliaments.

So, the average confidence in the European Parliament, though small compared to the confidence in other institutions -4.4 on a 10 -point scale - but there are no significant differences in the indicators across countries. This is the first feature.

The second feature is that when considering the EP and UN confidence index in dynamics, it can be noted that the number of countries with negative dynamics is almost double the number of countries with positive dynamics, and the other trend is the opposite (see Figures 5, 6). From an institutional approach, this fact looks like an unforeseen deterioration in the quality of "exemplary" political institutions.

\section{Conclusions}

The results of our empirical study prove that trust in political and public institutions is rationally justified; it is closely linked to the citizens' assessment of the work of the institutes. Institutions that work well build trust - the police, the courts, the European Parliament and the UN; poorly performing institutions produce skepticism and mistrust political parties, politicians, national parliament.

An empirical analysis of the dependence of the confidence level on the individual characteristics of the respondents in the countries of "democratic transit" and in the high-trust societies has made the following conclusions:

1) Institutional trust in these countries is significantly influenced by political and economic factors and, at the same time, is almost unaffected by interpersonal

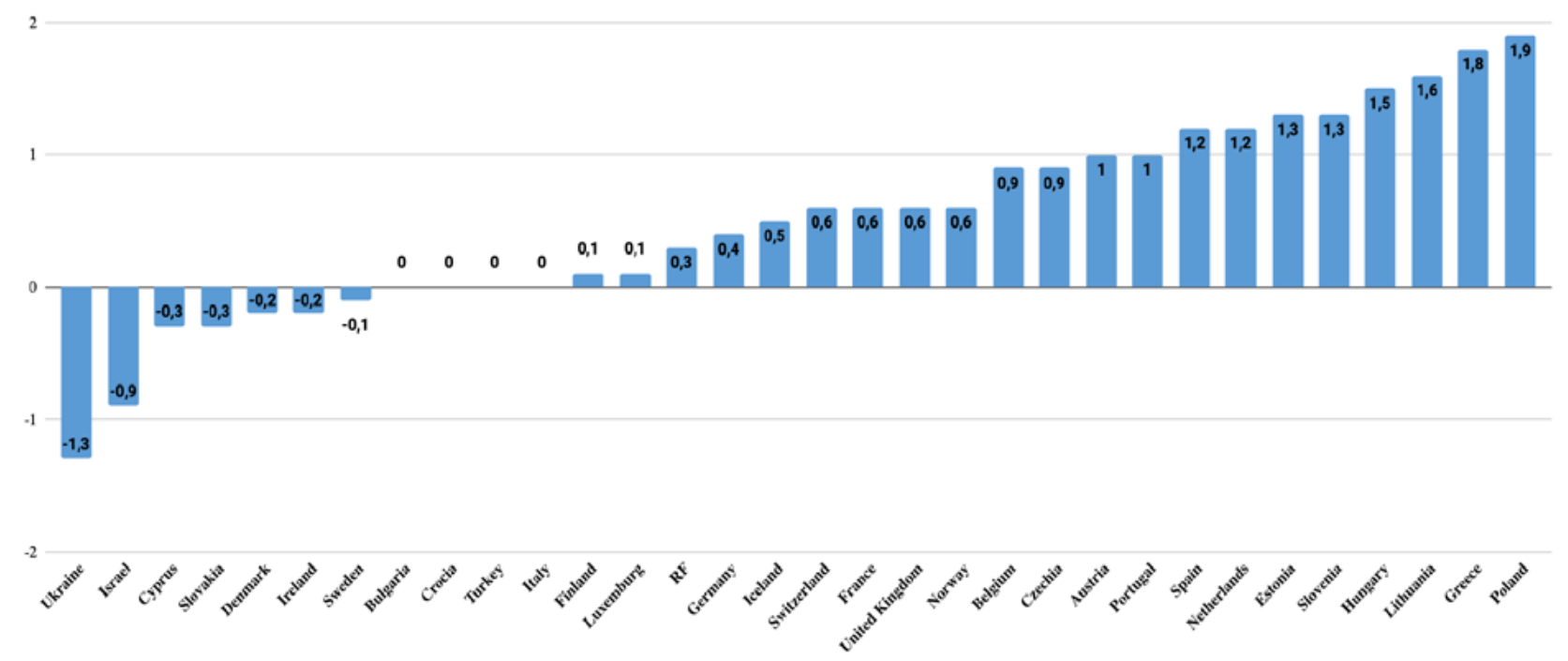

Figure 3. Dynamics of police confidence among ESS Round 1-9 project participants (difference in scores (10-point averages) between the first and last survey)

Source: authors 


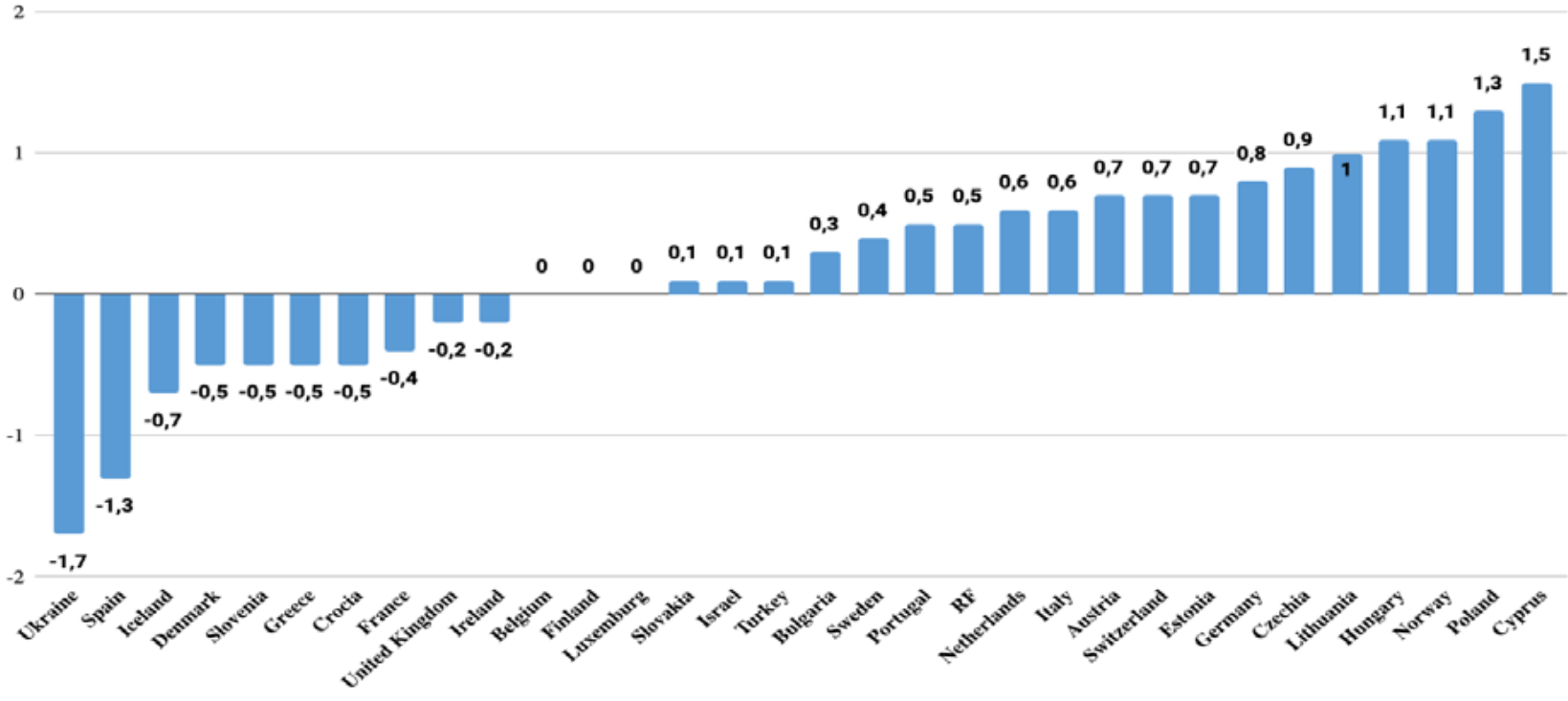

Figure 4. Dynamics of trust in political parties among ESS 2002-2019 project participants (difference in scores (10-point averages) between the first and last survey)

Source: authors

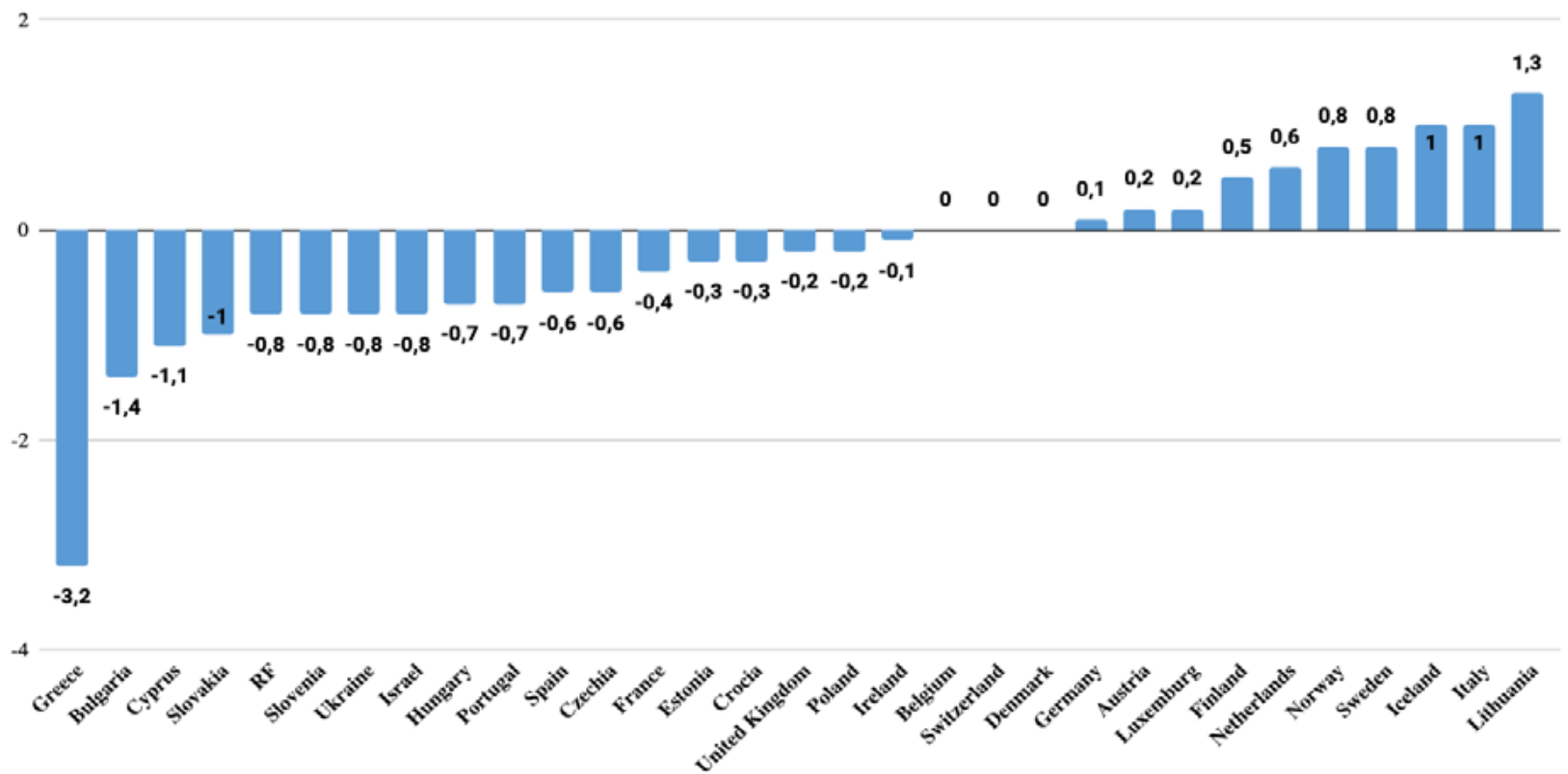

Figure 5. Dynamics of confidence in the European Parliament among ESS 2002-2019 countries (difference in scores (10 point average) between the first and last survey)

Source: authors

trust or the particularities of socialization of individuals.

2) The police and the judiciary stand out from other public institutions. High level in modern developed societies with dense networks of social ties and voluntary associations, where political institutions (courts, police) work in a way that compels or encourages individuals to have a reliable, responsible, trusting behavior, a level of all kinds of trust, which in turn has a reverse effect on political institutions.
This is the pattern we have found in "high-confidence societies" to which, for example, modern Scandinavian societies belong: Denmark, Norway, Switzerland, Finland [Annex 1-5].

3) All of the above is about the activities of public institutions to build institutional trust, and is mainly about high-trust societies, that is, Western Europe. Ukrainian society is usually referred to as a lowconfidence society. Do high and low trust societies share the same patterns? In our opinion, political 
2

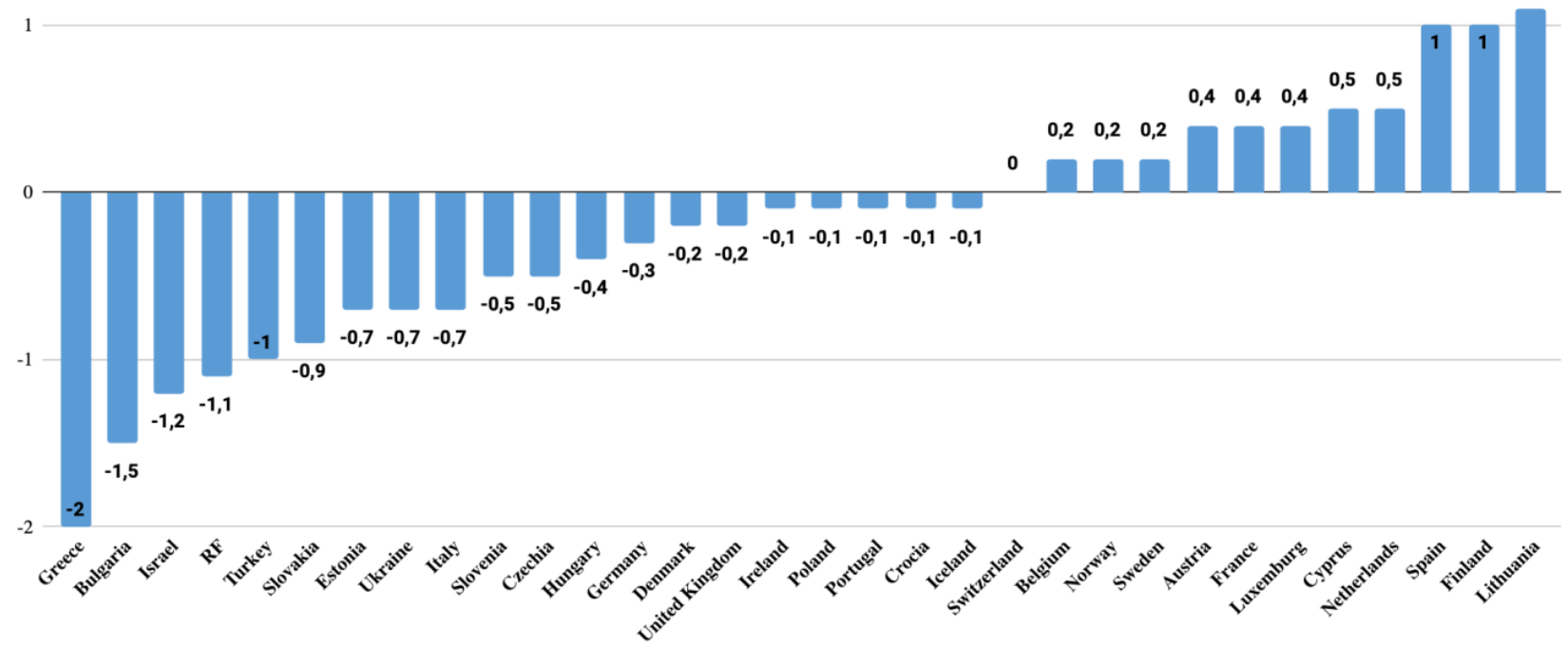

Figure 6. Dynamics of United Nations confidence among ESS 2002-2019 project participants (difference in scores (10-point averages) between the first and last survey)

Source: authors

trust (or distrust) is formed mainly by the activities of political institutions (respectively, effective and just, or ineffective and unjust), and people's social characteristics play a lesser role in this.

4) Let us dwell on this conclusion in more detail. When addressing the topic of the activities of political institutions, it is natural to question the criteria for their effectiveness. In general, public institutions can be regarded as systems of formal rules or systems of roles. A public institute works effectively if, in the opinion of the participants or observers, it is functional: the "performers" cope with their roles, they meet the expectations placed on them by the citizens. In the English-language literature on institutional confidence, the term performance is used to express the performance of the institute, which indicates the visible, observable effect of the activity. The effect (or inconsistency) of expectations is, in our opinion, the most important in the context of trust in public institutions. Of course, the "effectiveness" of public institutions can be measured in any other way that is not related to people's evaluation. In this study, we proceed from an assessment of the effectiveness of political institutes through a generalized, indirect, positive opinion regarding citizens' satisfaction with the living conditions and activities of political institutions.

5) Thus, the issue of scientific consideration of a number of problems related not only to the definition of the essence and content of the concept of "institutional trust", but also to the mechanisms of its formation, structure, measurement indicators at the interstate, state and regional and local levels in recent decades, growing relevance. After all, along with the dynamic development of globalization and counterglobalization processes in various spheres of society (world economy, social, humanitarian, environmental, scientific and technical components of sustainable development) increases the nonlinearity of these processes and uncertainty in achieving positive outcomes of institutional change. the need for active formation of institutional trust in the system of public administration. After all, the process of development of the public administration system is a process of self-identification taking into account the positive and negative experiences of the past in changing conditions. 
Vol. 1, No. 4, 2020

Three Seas Economic Journal

Annex 1

Trust in country's parliament (ESS, mean)

\begin{tabular}{|c|c|c|c|c|c|c|c|c|c|c|c|}
\hline & $\begin{array}{c}\text { Round } 1 \\
(2002)\end{array}$ & $\begin{array}{c}\text { Round } 2 \\
(2004)\end{array}$ & $\begin{array}{c}\text { Round } 3 \\
(2006)\end{array}$ & $\begin{array}{c}\text { Round } 4 \\
(2008)\end{array}$ & $\begin{array}{c}\text { Round 5 } \\
(2010)\end{array}$ & $\begin{array}{c}\text { Round } 6 \\
(2012)\end{array}$ & $\begin{array}{c}\text { Round } 7 \\
(2014)\end{array}$ & $\begin{array}{c}\text { Round } 8 \\
(2016)\end{array}$ & $\begin{array}{c}\text { Round } 9 \\
(2018)\end{array}$ & $\begin{array}{c}\text { Index } \\
\text { Country } \\
\text { (mean) }\end{array}$ & Delta \\
\hline Austria & 5.1 & 4.8 & 4.9 & & & & 4.7 & 5.0 & 5.4 & 5.0 & 0.4 \\
\hline Belgium & 5.0 & 4.7 & 5.0 & 4.6 & 4.5 & 4.9 & 4.8 & 4.8 & 4.8 & 4.8 & -0.2 \\
\hline Bulgaria & & & 2.2 & 1.9 & 2.4 & 2.3 & & & 2.5 & 2.3 & 0.3 \\
\hline Switzerland & 5.8 & 5.5 & 5.7 & 5.8 & 5.8 & 6.5 & 6.2 & 6.3 & 6.4 & 6.0 & 0.6 \\
\hline Cyprus & & & 5.7 & 5.6 & 4.6 & 4.7 & & & 3.7 & 4.9 & -0.8 \\
\hline Germany & 4.5 & 4.2 & 4.1 & 4.7 & 4.3 & 6.0 & 5.1 & 5.3 & 5.1 & 4.8 & 0.6 \\
\hline Denmark & 6.2 & 6.3 & 6.4 & 6.5 & 5.8 & 7.7 & 5.9 & & & 6.4 & -0.3 \\
\hline Estonia & & 4.2 & 4.6 & 3.9 & 4.2 & 4.9 & 4.4 & 4.5 & 4.9 & 4.4 & 0.7 \\
\hline Spain & 4.8 & 5.1 & 5.0 & 5.0 & 4.3 & 3.7 & 3.7 & 3.9 & & 4.4 & -0.9 \\
\hline Finland & 5.8 & 6.0 & 6.0 & 6.0 & 5.4 & 7.0 & 5.6 & 5.7 & 5.9 & 5.9 & 0.1 \\
\hline France & 4.5 & 4.3 & 4.3 & 4.5 & 4.2 & & 3.9 & 4.1 & 4.1 & 4.2 & -0.4 \\
\hline United Kingdom & 4.7 & 4.3 & 4.2 & 4.3 & 4.1 & 5.6 & 4.3 & 4.7 & 4.2 & 4.5 & -0.2 \\
\hline Hungary & 5.0 & 3.6 & 3.4 & 2.6 & 4.2 & 4.7 & 3.9 & 4.5 & 4.6 & 4.1 & -0.4 \\
\hline Ireland & 4.4 & 4.7 & 4.8 & 3.8 & 3.7 & 5.2 & 3.8 & 4.5 & 4.6 & 4.4 & 0.2 \\
\hline Netherlands & 5.2 & 4.7 & 5.3 & 5.6 & 5.4 & 6.1 & 5.2 & 5.6 & 5.9 & 5.4 & 0.7 \\
\hline Norway & 5.7 & 5.4 & 5.7 & 5.8 & 6.0 & 7.2 & 6.7 & 6.8 & 6.8 & 6.2 & 1.1 \\
\hline Poland & 3.5 & 2.4 & 2.7 & 3.0 & 3.4 & 3.7 & 2.8 & 3.4 & 3.8 & 3.2 & 0.3 \\
\hline Portugal & 4.4 & 3.7 & 3.8 & 3.5 & 2.9 & 3.5 & 3.1 & 3.9 & & 3.6 & -0.5 \\
\hline RF & & & 3.3 & 3.9 & 3.6 & 3.6 & 4.4 & 4.3 & 3.7 & 3.9 & 0.4 \\
\hline Sweden & 5.9 & 5.4 & 5.6 & 5.7 & 6.3 & 6.3 & 6.2 & 5.9 & & 5.9 & 0 \\
\hline Slovenia & 4.0 & 4.1 & 4.2 & 4.4 & 3.0 & 3.3 & 4.4 & 3.3 & 3.6 & 3.8 & -0.4 \\
\hline Slovakia & & 3.1 & 4.2 & 4.0 & 3.2 & 3.3 & & & & 3.6 & 0.2 \\
\hline Ukraine & & 4.8 & 2.4 & 1.7 & 2.0 & 1.9 & & & & 2.6 & -2.9 \\
\hline Israel & 4.7 & & & 3.8 & 3.7 & 5.6 & 4.1 & 4.1 & & 4.3 & -0.6 \\
\hline Czechia & 3.6 & 3.2 & & 3.3 & 3.3 & 4.1 & 4.0 & 4.3 & 4.2 & 3.7 & 0.6 \\
\hline Greece & 4.8 & 4.7 & & 3.6 & 2.0 & & & & & 3.8 & -2.8 \\
\hline Crocia & & & & 3.0 & 2.3 & & & & & 2.7 & -0.7 \\
\hline Lithuania & & & & & 2.3 & & 3.3 & 3.9 & & 3.2 & 1.7 \\
\hline Turkey & & 6.3 & & 5.9 & & & & & & 6.1 & -0.4 \\
\hline Iceland & & 5.9 & & & & 5.8 & & 5.1 & & 5.6 & -0.7 \\
\hline Luxemburg & 5.7 & 5.8 & & & & & & & & 5.8 & 0.1 \\
\hline Italy & 4.8 & & & & & & & 3.2 & 4.3 & 4.1 & -0.5 \\
\hline Mean (Round) & 4.9 & 4.5 & 4.5 & 4.3 & 4.2 & 4.9 & 4.6 & 4.7 & 4.7 & 4.5 & \\
\hline St.def (Round) & 0.8 & 1.0 & 1.2 & 1.3 & 1.2 & 1.6 & 1.0 & 0.9 & 1.1 & 1.1 & \\
\hline Upper limit of norm & 5.6 & 5.5 & 5.6 & 5.6 & 5.3 & 6.4 & 5.7 & 5.7 & 5.8 & 5.6 & \\
\hline Lower limit of norm & 4.1 & 3.5 & 3.3 & 3.0 & 3.0 & 3.3 & 3.6 & 3.8 & 3.6 & 3.4 & \\
\hline
\end{tabular}


Annex 2

Trust in the police (ESS, mean)

\begin{tabular}{|c|c|c|c|c|c|c|c|c|c|c|c|}
\hline & $\begin{array}{c}\text { Round1 } \\
(2002)\end{array}$ & $\begin{array}{c}\text { Round } 2 \\
(2004)\end{array}$ & $\begin{array}{c}\text { Round } 3 \\
(2006)\end{array}$ & $\begin{array}{c}\text { Round } 4 \\
(2008)\end{array}$ & $\begin{array}{c}\text { Round } 5 \\
(2010)\end{array}$ & $\begin{array}{c}\text { Round } 6 \\
(2012)\end{array}$ & $\begin{array}{c}\text { Round } 7 \\
(2014)\end{array}$ & $\begin{array}{c}\text { Round } 8 \\
(2016)\end{array}$ & $\begin{array}{c}\text { Round 9 } \\
(2018)\end{array}$ & $\begin{array}{c}\text { Index } \\
\text { Country } \\
\text { (mean) }\end{array}$ & Delta \\
\hline Austria & 6.4 & 6.2 & 6.3 & & & & 6.5 & 7.1 & 7.4 & 6.7 & 1 \\
\hline Belgium & 5.6 & 5.8 & 5.9 & 6.0 & 6.0 & 6.1 & 6.0 & 6.4 & 6.5 & 6.0 & 0.9 \\
\hline Bulgaria & & & 3.8 & 3.3 & 3.9 & 3.6 & & & 3.8 & 3.7 & 0 \\
\hline Switzerland & 6.8 & 6.9 & 6.9 & 6.9 & 7.0 & 7.2 & 7.2 & 7.2 & 7.4 & 7.1 & 0.6 \\
\hline Cyprus & & & 5.6 & 5.9 & 5.5 & 4.9 & & & 5.3 & 5.4 & -0.3 \\
\hline Germany & 6.7 & 6.5 & 6.5 & 6.8 & 6.9 & 6.9 & 6.8 & 7.1 & 7.1 & 6.8 & 0.4 \\
\hline Denmark & 7.9 & 7.9 & 7.8 & 7.6 & 7.7 & 8.0 & 7.7 & & & 7.8 & -0.2 \\
\hline Estonia & & 5.7 & 5.5 & 6.1 & 6.2 & 5.9 & 6.1 & 6.8 & 7.0 & 6.2 & 1.3 \\
\hline Spain & 5.4 & 5.9 & 6.0 & 6.1 & 6.3 & 5.9 & 6.3 & 6.6 & & 6.1 & 1.2 \\
\hline Finland & 8.0 & 8.0 & 8.1 & 8.0 & 8.0 & 8.1 & 7.9 & 8.2 & 8.1 & 8.0 & 0.1 \\
\hline France & 5.9 & 5.8 & 5.8 & 5.8 & 5.6 & & 6.1 & 6.4 & 6.5 & 6.0 & 0.6 \\
\hline United Kingdom & 6.0 & 6.1 & 6.0 & 6.2 & 6.2 & 6.5 & 6.3 & 6.7 & 6.6 & 6.3 & 0.6 \\
\hline Hungary & 4.9 & 5.2 & 5.2 & 4.3 & 5.1 & 5.3 & 5.3 & 6.4 & 6.4 & 5.3 & 1.5 \\
\hline Ireland & 6.5 & 6.6 & 6.2 & 6.5 & 6.5 & 6.6 & 6.3 & 6.2 & 6.3 & 6.4 & -0.2 \\
\hline Netherlands & 5.8 & 6.0 & 6.2 & 6.3 & 6.3 & 6.4 & 6.4 & 6.7 & 7.0 & 6.3 & 1.2 \\
\hline Norway & 7.0 & 7.1 & 7.2 & 7.0 & 7.2 & 7.2 & 7.4 & 7.4 & 7.6 & 7.2 & 0.6 \\
\hline Poland & 4.9 & 4.6 & 5.0 & 5.1 & 5.4 & 5.3 & 5.1 & 5.7 & 5.8 & 5.2 & 1.9 \\
\hline Portugal & 5.1 & 5.1 & 5.2 & 5.3 & 5.1 & 5.3 & 5.6 & 6.1 & & 5.3 & 1 \\
\hline RF & & & 3.4 & 3.7 & 3.5 & 3.5 & 4.4 & 4.4 & 3.7 & 3.8 & 0.3 \\
\hline Sweden & 6.8 & 6.5 & 6.5 & 6.6 & 7.0 & 6.7 & 6.9 & 6.7 & & 6.7 & -0.1 \\
\hline Slovenia & 4.9 & 4.7 & 5.0 & 5.0 & 5.0 & 5.3 & 5.5 & 6.0 & 6.2 & 5.3 & 1.3 \\
\hline Slovakia & & 4.4 & 4.7 & 4.8 & 4.5 & 4.1 & & & & 4.5 & -0.3 \\
\hline Ukraine & & 3.3 & 2.5 & 2.3 & 2.5 & 2.0 & & & & 2.5 & -1.3 \\
\hline Israel & 6.3 & & & 4.8 & 4.8 & 5.1 & 4.8 & 5.2 & & 5.2 & -0.9 \\
\hline Czechia & 5.0 & 4.2 & & 4.8 & 4.9 & 5.1 & 5.7 & 5.8 & 5.9 & 5.2 & 0.9 \\
\hline Greece & 6.4 & 6.0 & & 4.9 & 4.6 & & & & & 5.5 & 1.8 \\
\hline Crocia & & & & 4.4 & 4.4 & & & & & 4.4 & 0 \\
\hline Lithuania & & & & & 4.5 & & 5.7 & 6.1 & & 5.4 & 1.6 \\
\hline Turkey & & 6.5 & & 6.5 & & & & & & 6.5 & 0 \\
\hline Iceland & & 7.3 & & & & 7.8 & & 7.8 & & 7.6 & 0.5 \\
\hline Luxemburg & 6.4 & 6.5 & & & & & & & & 6.5 & 0.1 \\
\hline Italy & 6.7 & & & & & & & 6.1 & 6.7 & 6.5 & 0 \\
\hline Mean (Round) & 6.1 & 5.8 & 5.7 & 5.6 & 5.7 & 5.7 & 6.2 & 6.5 & 6.5 & 5.8 & \\
\hline St.def (Round) & 1.0 & 1.2 & 1.3 & 1.4 & 1.3 & 1.5 & 0.9 & 0.8 & 1.0 & 1.3 & \\
\hline Upper limit of norm & 7.1 & 7.0 & 7.0 & 7.0 & 7.0 & 7.2 & 7.1 & 7.3 & 7.5 & 7.1 & \\
\hline Lower limit of norm & 5.1 & 4.6 & 4.4 & 4.3 & 4.4 & 4.2 & 5.3 & 5.6 & 5.5 & 4.5 & \\
\hline
\end{tabular}


Vol. 1, No. 4, 2020

Three Seas Economic Journal

Annex 3

Trust in political parties (ESS, mean)

\begin{tabular}{|c|c|c|c|c|c|c|c|c|c|c|}
\hline & $\begin{array}{c}\text { Round } 2 \\
(2004)\end{array}$ & $\begin{array}{c}\text { Round } 3 \\
(2006)\end{array}$ & $\begin{array}{c}\text { Round } 4 \\
(2008)\end{array}$ & $\begin{array}{l}\text { Round } 5 \\
(2010)\end{array}$ & $\begin{array}{c}\text { Round } 6 \\
(2012)\end{array}$ & $\begin{array}{c}\text { Round } 7 \\
(2014)\end{array}$ & $\begin{array}{c}\text { Round } 8 \\
(2016)\end{array}$ & $\begin{array}{c}\text { Round } 9 \\
(2018)\end{array}$ & $\begin{array}{c}\text { Index } \\
\text { Country } \\
\text { (mean) }\end{array}$ & Delta \\
\hline Austria & 3.4 & 3.4 & & & & 3.4 & 3.8 & 4.1 & 3.6 & 0.7 \\
\hline Belgium & 4.3 & 4.4 & 4.0 & 3.9 & 4.2 & 4.1 & 4.0 & 4.3 & 4.1 & 0 \\
\hline Bulgaria & & 1.8 & 1.7 & 2.0 & 1.8 & & & 2.1 & 1.9 & 0.3 \\
\hline Switzerland & 4.6 & 4.7 & 4.7 & 4.8 & 5.0 & 5.1 & 5.2 & 5.3 & 4.9 & 0.7 \\
\hline Cyprus & & 4.2 & 4.4 & 3.5 & 2.4 & & & 2.7 & 3.4 & 1.5 \\
\hline Germany & 3.2 & 3.2 & 3.5 & 3.4 & 3.8 & 3.9 & 4.2 & 4.0 & 3.6 & 0.8 \\
\hline Denmark & 5.6 & 5.7 & 5.7 & 5.2 & 5.3 & 5.1 & & & 5.4 & -0.5 \\
\hline Estonia & 3.1 & 3.5 & 3.2 & 3.4 & 3.2 & 3.4 & 3.6 & 3.8 & 3.4 & 0.7 \\
\hline Spain & 3.7 & 3.5 & 3.2 & 2.7 & 1.9 & 2.2 & 2.4 & & 2.8 & -1.3 \\
\hline Finland & 5.0 & 5.0 & 5.0 & 4.5 & 1.9 & 4.7 & 4.8 & 5.0 & 4.5 & 0 \\
\hline France & 3.4 & 3.2 & 3.4 & 3.1 & & 2.7 & 2.8 & 3.0 & 3.1 & -0.4 \\
\hline United Kingdom & 3.7 & 3.5 & 3.6 & 3.5 & 3.7 & 3.5 & 3.8 & 3.5 & 3.6 & -0.2 \\
\hline Hungary & 2.7 & 2.6 & 2.0 & 3.1 & 4.2 & 3.0 & 3.6 & 3.8 & 3.1 & 1.1 \\
\hline Ireland & 4.0 & 3.9 & 3.3 & 3.1 & 3.0 & 3.3 & 3.7 & 3.8 & 3.5 & -0.2 \\
\hline Netherlands & 4.8 & 5.1 & 5.2 & 5.3 & 5.1 & 4.9 & 5.2 & 5.4 & 5.1 & 0.6 \\
\hline Norway & 4.3 & 4.5 & 4.8 & 4.9 & 5.2 & 5.3 & 5.5 & 5.4 & 5.0 & 1.1 \\
\hline Poland & 1.9 & 2.1 & 2.3 & 2.5 & 2.2 & 2.0 & 2.4 & 3.2 & 2.3 & 1.3 \\
\hline Portugal & 2.1 & 2.6 & 2.4 & 2.0 & 1.8 & 2.2 & 2.6 & & 2.2 & 0.5 \\
\hline RF & & 2.8 & 3.2 & 3.1 & 3.0 & 3.8 & 3.6 & 3.3 & 3.2 & 0.5 \\
\hline Sweden & 4,4 & 4.6 & 4.8 & 5.1 & 4.9 & 5.1 & 4.8 & & 4.8 & 0.4 \\
\hline Slovenia & 3.2 & 3.3 & 3.4 & 2.2 & 2.3 & 2.0 & 2.5 & 2.7 & 2.7 & -0.5 \\
\hline Slovakia & 2.7 & 3.6 & 3.6 & 2.7 & 2.8 & & & & 3.1 & 0.1 \\
\hline Ukraine & 3.6 & 2.2 & 1.7 & 2.0 & 1.9 & & & & 2.3 & -1.7 \\
\hline Israel & & & 3.0 & 3.0 & 3.1 & 3.2 & 3.1 & & 3.1 & 0.1 \\
\hline Czechia & 2.7 & & 2.9 & 2.7 & 2.7 & 3.4 & 3.5 & 3.6 & 3.1 & 0.9 \\
\hline Greece & 3.5 & & 2.5 & 1.4 & & 3.0 & & & 2.6 & -0.5 \\
\hline Crocia & & & 2.3 & 1.8 & & & & & 2,1 & -0.5 \\
\hline Lithuania & & & & 2.2 & & & 3.2 & & 2.7 & \\
\hline Turkey & 3.1 & & 3.2 & & & & & & 3.2 & 0.1 \\
\hline Iceland & 4.9 & & & & 3.5 & & 4.2 & & 4.2 & -0.7 \\
\hline Luxemburg & 5.0 & & & & & & & & 5.0 & 0 \\
\hline Italy & & & & & & & 2.3 & 2.9 & 2.6 & 0.6 \\
\hline Mean (Round) & 3.6 & 3.6 & 3.5 & 3.4 & 3.3 & 3.6 & 3.8 & 3.9 & 3.5 & \\
\hline St.def (Round) & 1.0 & 1.0 & 1.1 & 1.1 & 1.2 & 1.1 & 1.0 & 1.0 & 1.0 & \\
\hline Upper limit of norm & 4.6 & 4.6 & 4.6 & 4.5 & 4.5 & 4.7 & 4.7 & 4.8 & 4.5 & \\
\hline Lower limit of norm & 2.7 & 2.6 & 2.4 & 2.4 & 2.1 & 2.5 & 2.8 & 2.9 & 2.5 & \\
\hline
\end{tabular}


Annex 4

Trust in the European Parliament (ESS, mean)

\begin{tabular}{|c|c|c|c|c|c|c|c|c|c|c|c|}
\hline & $\begin{array}{c}\text { Round } 1 \\
(2002)\end{array}$ & $\begin{array}{c}\text { Round } 2 \\
(2004)\end{array}$ & $\begin{array}{c}\text { Round } 3 \\
(2006)\end{array}$ & $\begin{array}{c}\text { Round } 4 \\
(2008)\end{array}$ & $\begin{array}{c}\text { Round 5 } \\
(2010)\end{array}$ & $\begin{array}{c}\text { Round } 6 \\
(2012)\end{array}$ & $\begin{array}{c}\text { Round } 7 \\
(2014)\end{array}$ & $\begin{array}{c}\text { Round } 8 \\
(2016)\end{array}$ & $\begin{array}{c}\text { Round } 9 \\
(2018)\end{array}$ & $\begin{array}{c}\text { Index } \\
\text { Country } \\
\text { (mean) }\end{array}$ & Delta \\
\hline Austria & 4.2 & 4.0 & 4.0 & & & & 3.6 & 3.8 & 4.4 & 4.0 & 0.2 \\
\hline Belgium & 4.9 & 5.0 & 5.1 & 5.1 & 5.0 & 5.1 & 4.8 & 4.6 & 4.9 & 5.0 & 0 \\
\hline Bulgaria & & & 4.6 & 4.6 & 4.8 & 4.3 & & & 3.2 & 4.3 & -1.4 \\
\hline Switzerland & 4.8 & 4.6 & 4.7 & 4.8 & 4.6 & 4.7 & 4.5 & 4.5 & 4.8 & 4.7 & 0 \\
\hline Cyprus & & & 5.8 & 6.0 & 5.0 & 4.3 & & & 4.7 & 5.2 & -1.1 \\
\hline Germany & 4.5 & 4.2 & 4.0 & 4.3 & 4.0 & 4.4 & 4.1 & 4.4 & 4.6 & 4.3 & 0.1 \\
\hline Denmark & 4.8 & 4.8 & 5.0 & 5.0 & 5.0 & 5.2 & 4.8 & & & 5.0 & 0 \\
\hline Estonia & & 4.9 & 5.3 & 5.0 & 5.2 & 4.7 & 4.4 & 4.6 & 4.6 & 4.8 & -0.3 \\
\hline Spain & 4.8 & 5.1 & 5.0 & 5.0 & 4.5 & 3.9 & 3.9 & 4.2 & & 4.5 & -0.6 \\
\hline Finland & 4.9 & 5.0 & 5.0 & 5.2 & 5.1 & 5.0 & 4.7 & 5.2 & 5.4 & 5.1 & 0.5 \\
\hline France & 4.4 & 4.3 & 4.3 & 4.6 & 4.3 & & 3.9 & 3.7 & 4.0 & 4.2 & -0.4 \\
\hline United Kingdom & 3.6 & 3.5 & 3.4 & 3.6 & 3.4 & 3.4 & 3.1 & 3.7 & 3.4 & 3.4 & -0.2 \\
\hline Hungary & 5.7 & 5.2 & 5.0 & 4.0 & 4.7 & 3.9 & 4.8 & 4.4 & 5.0 & 4.6 & -0.7 \\
\hline Ireland & 5.1 & 5.4 & 5.2 & 4.7 & 4.1 & 4.4 & 4.6 & 4.9 & 5.0 & 4.8 & -0.1 \\
\hline Netherlands & 4.7 & 4.6 & 4.7 & 5.1 & 4.9 & 4.8 & 4.5 & 4.7 & 5.3 & 4.8 & 0.6 \\
\hline Norway & 4.7 & 4.6 & 4.7 & 5.0 & 5.0 & 4.9 & 5.0 & 5.1 & 5.5 & 5.0 & 0.8 \\
\hline Poland & 4.8 & 4.3 & 4.8 & 4.5 & 4.7 & 4.2 & 3.6 & 3.9 & 4.6 & 4.3 & -0.2 \\
\hline Portugal & 4.8 & 4.0 & 4.6 & 4.3 & 3.7 & 3.2 & 3.4 & 4.1 & & 3.9 & -0.7 \\
\hline RF & & & 3.9 & & & 3.6 & 2.8 & 2.8 & 3.1 & 3.3 & -0.8 \\
\hline Sweden & 4.0 & 4.0 & 4.5 & 4.7 & 5.0 & 4.7 & 4.7 & 4.8 & & 4.6 & 0.8 \\
\hline Slovenia & 4.6 & 4.5 & 5.0 & 4.8 & 3.7 & 3.8 & 3.4 & 3.9 & 3.8 & 4.1 & -0.8 \\
\hline Slovakia & & 4.7 & 5.1 & 5.2 & 4.4 & 3.7 & & & & 4.6 & -1 \\
\hline Ukraine & & 4.8 & 3.6 & 3.6 & 4.0 & & & & & 4.0 & -0.8 \\
\hline Israel & 4.1 & & & 3.9 & 3.4 & 4.0 & 3.2 & 3.3 & & 3.6 & -0.8 \\
\hline Czechia & 4.7 & 4.4 & & 3.9 & 4.1 & 3.9 & 4.2 & 4.2 & 4.1 & 4.1 & -0.6 \\
\hline Greece & 5.8 & 5.3 & & 4.4 & 2.6 & & & & & 4.1 & -3.2 \\
\hline Crocia & & & & 3.6 & 3.3 & & & & & 3.5 & -0.3 \\
\hline Lithuania & & & & & 4.3 & & 5.2 & 5.6 & & 5.0 & 1.3 \\
\hline Iceland & & & & & & 4.2 & & 5.2 & & 4.7 & 1 \\
\hline Luxemburg & 5 & 5.2 & & & & & & & & 5.1 & 0.2 \\
\hline Italy & 5.5 & & & & & & & 4.0 & 4.4 & 4.2 & 1 \\
\hline Mean (Round) & 4.6 & 4.6 & 4.7 & 4.6 & 4.5 & 4.3 & 4.1 & 4.2 & 4.5 & 4.4 & \\
\hline St.def (Round) & 0.5 & 0.5 & 0.6 & 0.6 & 0.6 & 0.6 & 0.7 & 0.6 & 0.7 & 0.5 & \\
\hline Upper limit of norm & 5.1 & 5.0 & 5.2 & 5.2 & 5.0 & 4.8 & 4.8 & 4.8 & 5.2 & 4.9 & \\
\hline Lower limit of norm & 4.2 & 4.1 & 4.1 & 4.1 & 3.9 & 3.7 & 3.4 & 3.6 & 3.9 & 3.9 & \\
\hline
\end{tabular}


Vol. 1, No. 4, 2020

Three Seas Economic Journal

Annex 5

Trust in the United Nations (ESS, mean)

\begin{tabular}{|c|c|c|c|c|c|c|c|c|c|c|c|}
\hline & $\begin{array}{c}\text { Round1 } \\
(2002)\end{array}$ & $\begin{array}{c}\text { Round2 } \\
(2004)\end{array}$ & $\begin{array}{c}\text { Round3 } \\
(2006)\end{array}$ & $\begin{array}{l}\text { Round4 } \\
(2008)\end{array}$ & $\begin{array}{c}\text { Round5 } \\
(2010)\end{array}$ & $\begin{array}{c}\text { Round } 6 \\
(2012)\end{array}$ & $\begin{array}{c}\text { Round7 } \\
(2014)\end{array}$ & $\begin{array}{c}\text { Round } 8 \\
(2016)\end{array}$ & $\begin{array}{c}\text { Round } 9 \\
(2018)\end{array}$ & $\begin{array}{c}\text { Index } \\
\text { Country } \\
\text { (mean) }\end{array}$ & Delta \\
\hline Austria & 4.5 & 4.5 & 4.7 & & & & 4.4 & 4.4 & 4.9 & 4.6 & 0.4 \\
\hline Belgium & 5.1 & 5.1 & 5.3 & 5.3 & 5.3 & 5.5 & 5.2 & 5.3 & 5.3 & 5.3 & 0.2 \\
\hline Bulgaria & & & 4.8 & 4.8 & 4.9 & 4.6 & & & 3.3 & 4.5 & -1.5 \\
\hline Switzerland & 5.4 & 5.4 & 5.4 & 5.6 & 5.3 & 5.5 & 5.4 & 5.2 & 5.4 & 5.4 & 0 \\
\hline Cyprus & & & 4.2 & 4.8 & 4.4 & 3.7 & & & 4.7 & 4.4 & 0.5 \\
\hline Germany & 5.2 & 4.9 & 4.7 & 5.0 & 4.7 & 5.0 & 4.7 & 4.9 & 4.9 & 4.9 & -0.3 \\
\hline Denmark & 6.5 & 6.6 & 6.5 & 6.5 & 6.2 & 6.6 & 6.3 & & & 6.5 & -0.2 \\
\hline Estonia & & & 5.6 & & 5.5 & 5.2 & 4.7 & 5.1 & 4.9 & 5.2 & -0.7 \\
\hline Spain & 4.7 & 5.5 & 5.0 & 5.0 & 4.9 & 4.7 & 4.8 & 4.7 & & 4.9 & 1 \\
\hline Finland & 6.5 & 6.6 & 6.5 & 6.7 & 6.6 & 6.5 & 6.2 & 6.4 & 6.5 & 6.5 & 1 \\
\hline France & 4.6 & 4.7 & 5.1 & 5.3 & 5.0 & & 5.1 & 4.9 & 5.0 & 5.0 & 0.4 \\
\hline United Kingdom & 5.3 & 5.2 & 5.0 & 5.1 & 4.9 & 5.2 & 4.9 & 5.3 & 5.1 & 5.1 & -0.2 \\
\hline Hungary & 6.0 & 5.7 & 5.5 & 4.5 & 5.1 & 4.9 & 5.4 & 5.0 & 5.6 & 5.2 & -0.4 \\
\hline Ireland & 5.7 & 5.8 & 5.7 & 5.6 & 5.3 & 5.5 & 5.4 & 5.7 & 5.6 & 5.6 & -0.1 \\
\hline Netherlands & 5.4 & 5.4 & 5.4 & 5.6 & 5.6 & 5.7 & 5.5 & 5.7 & 5.9 & 5.6 & 0.5 \\
\hline Norway & 6.8 & 6.9 & 6.8 & 6.8 & 6.7 & 6.7 & 6.7 & 6.8 & 7.0 & 6.8 & 0.2 \\
\hline Poland & 5.6 & 5.0 & 5.3 & 5.1 & 5.3 & 5.0 & 4.6 & 4.9 & 5.5 & 5.1 & -0.1 \\
\hline Portugal & 5.4 & 4.7 & 4.9 & 4.9 & 4.3 & 4.1 & 4.6 & 5.3 & & 4.7 & -0.1 \\
\hline RF & & & 4.3 & 4.1 & 4.4 & 3.7 & 2.8 & 3.0 & 3.4 & 3.7 & -1.1 \\
\hline Sweden & 6.0 & 6.3 & 6.4 & 6.4 & 6.3 & 6.3 & 6.4 & 6.2 & & 6.3 & 0.2 \\
\hline Slovenia & 4.9 & 4.6 & 5.1 & 5.0 & 4.1 & 4.2 & 4.2 & 4.3 & 4.4 & 4.5 & -0.5 \\
\hline Slovakia & & 5.2 & 5.3 & 5.4 & 4.8 & 4.3 & & & & 5.0 & -0.9 \\
\hline Ukraine & & 4.7 & 3.5 & 3.6 & 4.0 & & & & & 4.0 & -0.7 \\
\hline Israel & 4.0 & & & 3.9 & 3.4 & 3.6 & 3.0 & 2.8 & & 3.3 & -1.2 \\
\hline Czechia & 5.3 & 4.9 & & 4.8 & 4.9 & 4.8 & 4.8 & 5.0 & 4.8 & 4.9 & -0.5 \\
\hline Greece & 4.6 & 4.0 & & 4.0 & 2.6 & & & & & 3.5 & -2 \\
\hline Crocia & & & & 4.0 & 3.9 & & & & & 4.0 & -0.1 \\
\hline Lithuania & & & & & 4.7 & & 5.6 & 5.8 & & 5.4 & 1.1 \\
\hline Turkey & & 4.2 & & 3.2 & & & & & & 3.7 & -1 \\
\hline Iceland & & 6.7 & & & & 6.3 & & 6.6 & & 6.5 & -0.1 \\
\hline Luxemburg & 5.1 & 5.5 & & & & & & & & 5.5 & 0.4 \\
\hline Italy & 5.6 & & & & & & & 4.5 & 4.9 & 4.7 & -0.7 \\
\hline Mean (Round) & 5.4 & 5.4 & 5.3 & 5.2 & 5.1 & 5.1 & 5.0 & 5.0 & 5.2 & 5.1 & \\
\hline St.def (Round) & 0.7 & 0.7 & 0.8 & 0.8 & 0.8 & 0.9 & 1.0 & 1.0 & 0.8 & 0.8 & \\
\hline Upper limit of norm & 6.1 & 6.1 & 6.0 & 6.0 & 5.9 & 6.0 & 6.0 & 6.0 & 6.0 & 5.9 & \\
\hline Lower limit of norm & 4.7 & 4.7 & 4.5 & 4.4 & 4.3 & 4.1 & 4.0 & 4.1 & 4.4 & 4.2 & \\
\hline
\end{tabular}




\section{References:}

Sztompka, P. (2012). Trust is the basis of society. Transl. from Polish N. V. Morozova. Moscow: Logos.

Lukin, V. N. (2005). Political trust in modern civil society: cultural and institutional models. Moscow: Credo New. Available at: http://credonew.ru/content/view/500/30/

Terin, D. F. (2018). The construction of political trust in Russia: the effectiveness and justice of political institutions. Sociological Journal, vol. 24, no. 2, pp. 90-109.

Baker Kendall (1981). Germany Transformed: Political Culture and the New Politics. Harvard University Press. Inglehart, R., \& Welzel, C. (2005). Modernization, cultural change, and democracy: The human development sequence.

Keenan, E. (1986). Muscovites Political Folkways. Russian Review, vol. 45, pp. 115-181.

Jowitt, K. (1992). New World Order: The Leninist Extinction. Berkeley: University of California Press.

Hedland, S. (1999). Russia’s Market Economy: A Bad Case of Predatory Capitalism. London: UCL Press.

Joyce, J. M. (1984). The Old Russian Legacy. Foreign Policy, vol. 55, pp. 132-153.

Fukuyama, F. (1995). Trust: the social virtues and the creation of prosperity. New York: The free press.

Rose, R. (1995). Russia as an Hour-Gluss Society: A Constitution Withhout Citizens. East European Constitutional Review, vol. 4, no. 3, pp. 34-42.

Newton, K. (1999). Social and Political Trust in Established Democracies. Critical Citizens: Global Support for Democratic Governance. Pippa Norris Ed. Oxford, UK: Oxford University Press.

Mutz, D. (1998). Impressional Influence. Cambridge, UK: Cambridge University Press.

Dasgupta, P. and Goyal, S. (2019). Narrow Identities. Journal of Institutional and Theoretical Economics, vol. 175, no. 3, pp. 395-419.

Skowronek, S. (1982). Building a New American State: The Expansion of National Administrative Capacities, 1877-1920: Cambridge University Press.

Shepsle, K. A. (2017). Rule Breaking and Political Imagination. Chicago: University of Chicago Press. 